\title{
СТРУКТУРНО-УРОВНЕВАЯ МОДЕЛЬ ОЦЕНКИ ГОТОВНОСТИ КАНДИДАТОВ В ПРИЁМНЫХ РОДИТЕЛИГ
}

\author{
Алдашева А. А. (Институт Психологии РАН, Москва, Россия) \\ aigulmama@mail.ru \\ Понамарева Е. А., Сапожникова Т. Н. (ГБУ центр «Детство», \\ psychoan@list.ru,sapozhnikova-tat@mail.ru

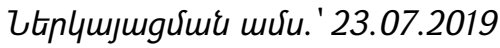

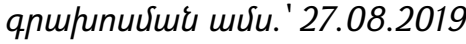

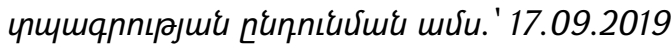 \\ В данной статье представлены теоретические и научно-практические
} Москва, Россия) предпосылки разработки системы отбора кандидатов в приёмные родители для приёма в семью детей сложной категории, представлена структурно-уровневая модель оценки готовности кандидатов в приёмных родители, описана процедура отбора кандидатов в приёмные родители.

Ключевые слова: приёмные родители, компетентность, отбор, сочиальнопсихологическая зрелость, готовность.

С фревраля 2014 г. Департаментом труда и социальной защиты населения города Москвы осуществляется реализация пилотного проекта по имущественной поддержке семей, принявших на воспитание по договорам о приемной семье 5 и более детей - сирот и детей, оставшихся без попечения родителей, из которых не менее трех детей в возрасте старше 10 лет и (или) дети-инвалиды. В рамках условий проекта нами была разработана система отбора кандидатов для участия в пилотном проекте, который предполагает одновременный приём в семью детей сложной категории в количестве не менее пяти [10].

Модель профессиональной приемной семьи предполагает открытость границ семейной системы, готовность к приёму на воспитание детей сложной категории, оставшихся без попечения взрослых, готовность к сотрудничеству с социальными институтами помощи и с органами опеки и попечительства. Большинство авторов (Герасимова Е.В.; Захарова Ж.А.; Лаврентьева 3. И.; Лифинцев Д.В.; Ослон В.Н.; Петрановская Л.В.) к основным функциям приемной семьи относят: 1) нравственное и фризическое воспитание, формирование ценностно-смысловой направленности личности приемного ребёнка; 2) коррекция негативных последствий пребывания ребенка сироты в интернатном учреждении либо в социально неблагополучной кровной семье; 3) ресоциализация (вторичная социализация) приемных детей, которая предполагает помощь ребёнку в освоении новых моделей поведения.

\footnotetext{
${ }^{5}$ Исследование выполнено при финансовой поддержке Грант РФФИ № 18-013-00118
} 
Среди фракторов, влияющих на эффрективность приемной семьи, согласно исследованиям, выделяются социально-демографические характеристики членов приемной семьи, особенности детско-родительских отношений и стили внутрисемейного взаимодействия, особенности взаимоотношений приёмных родителей с социальным окружением и государственными инстанциями (Алдашева А.А., Зеленова М.Е.; Махнач А.В., Прихожан А.М., Толстых Н.Н.; Швецова М.Н. и др.).

В целом, труд приемного родителя может охарактеризовать, как процесс поддержки жизненного пути ребенка в освоении социума и «сотворчества (освоение и созидание) духовных ценностей в ходе совместной деятельности субъектов воспитателей и воспитуемых» [6, с. 59]. Следовательно, одним из главных требований данного вида деятельности является умение взрослого формировать "субъект-субъектное» взаимодействие, основанное на индивидуальном подходе и определяемое индивидуальной историей ребенка-сироты.

Объективным подходом к решению задачи эфффективности приёмного родителя является, на наш взгляд, теоретико-методологический подход к определению социально-психологической зрелости (Л.И. Анцыферова, А.Л. Журавлев, Е.А. Сергиенко, С.К. Нартова-Бочавер и др.).

Данный подход позволяет выделить основные признаки социальнопсихологической зрелости как основания для построения критериев отбора кандидатов в приёмные родители. Мы выделяем общие компоненты социальнопсихологической зрелости, проявляющиеся в соответствующих сферах взаимодействия человека с другими людьми, а именно: 1) активности как способности к общественно значимой деятельности [5], владеть своим окружением, обладать устойчивым единством личностных черт и ценностных ориентаций [8]; 2) социальной ответственности как потребности личности разрешать противоречия жизни, осмысленно и конструктивно моделировать свой жизненный путь [7], как ответственности приёмного родителя перед собой, семьёй и обществом.[9]; 3) самостоятельности, независимости принятия решений как способности к интеграции идентичности, интериоризации этических ценностей, внутренней направленности мотивации, проявляющихся в контроле поведения [12]; 4) способности формировать доверительные отношения. [4; 9].

На основании теоретической модели приёмной семьи нами предпринята попытка разработки алгоритма оценки готовности к приёмному родительству. Методологической базой оценки готовности выступил компетентностный подход, описывающийся в терминах своеобразия (индивидуальности) эфффективного решения жизненных и профессиональных задач. Дж. Равен выделяет виды компетентностей: когнитивные, аффективные и волевые, обладающие свойствами независимости, взаимозависимости и взаимозаменяемости, рассматривающиеся в качестве интегрального свойства личности. Дж. Равен утверждал, что компетентность проявляется и развивается только в условиях интересной для человека 
деятельности, определял компоненты компетентности, как «мотивированные способности» [11].

Изучение профессиональной компетентности связано с рассмотрением взаимосвязи опыта, знаний, умений и отношения личности, как самостоятельных процессов направленных на достижение результата профессиональной деятельности.

Критерием компетентности выступает индивидуальный способ решения или своеобразие отношения человека к тому, что он делает. Это своеобразие проявляется в личностном отношении субъекта к выбору решения способа реализации.

С целью выделения признаков социально-психологической зрелости приёмных родителей в ГБУ Центре “Детство» совместно с институтом психологии Российской Академии Наук был проведен ряд исследований[1,2,3].

На основании эмпирических результатов была создана структурно-уровневая модель готовности кандидатов в приёмные родители к принятию в семью детейсирот сложной категории. Модель предполагает уровни анализа компонентов компетентности кандидатов, позволяющие оценить степень их готовности к созданию приёмной семьи.

Структурно-уровневая модель оценки готовности кандидатов в приёмных родители.

Уровни анализа индикаторов готовности к приёмному родительству:

a) микроуровень - семья;

b) метауровень - взаимодействие с разными институтами: школа, медицинские учреждения, органы опеки и попечительства, служба сопровождения;

с) макроуровень - способность к взаимодействию с сообществами приёмных родителей, общественными фондами, некоммерческими организациями, средствами массовой информации.

Индикаторы готовности к приёмному родительству:

\section{Оценка социально-психологической зрелости.}

- мотивы к приёмному родительству;

- просоциальная активность кандидата;

- социальная ответственность;

- самоотношение и отношение к другому.

\section{Оценка компетенций}

а) Воспитательные компетенции:

- способность к передачи семейных сценариев и ценностей;

- способность к формированию социальных норм и правил;

- способность планировать образовательный маршрут, осуществлять профессиональную ориентацию и содействовать профессиональному становлению приёмных детей, в том числе детей с ОВ3;

- способность к трансляции общегражданских ценностей. 
b) Организация семейной системы:

- тип семьи, внутрисемейные роли, семейные регуляторы;

- способность к реализации дополнительных функций приёмной семьи;

- способность выстраивать перспективу будущего приёмной семьи.

На основе структурно-уровневой модели оценки готовности кандидатов в приёмных родители нами разработана процедура отбора кандидатов. Были выделены следующие этапы.

Первый этап. Полуструктурированное интервью, направлено на прояснение: потребностно-мотивационной сферы граждан; понимания собственных рисков и ресурсов в качестве приёмных родителей; знаний об особенностях детей-сирот; способности встать на позицию приёмного ребёнка; умения планировать воспитательный процесс и анализировать полученный результат; умения формировать морально-ценностные установки и ценностно значимые качества личности ребёнка; способности реализовывать дополнительные функции приёмной семьи; умения взаимодействовать со специалистами социальных институтов. Прояснение наличия нежелательных черт характера приемного родителя.

Второй этап. Психологическое тестирование, которое проводится с целью определения личностных особенностей, в том числе способности выстраивать доверительные отношения; изучения родительских установок; наличия организаторских способностей и необходимых воспитательных компетенций.

Третий этап. Психологическое обследование семьи кандидатов по месту проживания с целью прояснения: особенностей организации семьи; характера взаимоотношений; наличия правил и традиций; типа семьи по принципу разделения власти и ответственности; открытости/закрытости семейной системы; стиля семейного воспитания; морально-нравственной атмосферы, способности выстраивать перспективу будущего своей семьи. Психологическая диагностика кровных детей с целью прояснения: удовлетворённости базовых потребностей, потребности в физической, психической, экономической безопасности; особенностей когнитивного и эмоционального развития; наличия индивидуальных перспектив будущего и профессионального самоопределения; подготовки к самостоятельной жизни.

Четвертый этап. На основании уровневого анализа индикаторов готовности делается заключение о социально-психологической зрелости кандидатов в приёмные родители, определяется их возможность участия в пилотном проекте.

\section{Выводы:}

1. Социально-психологическая зрелость кандидатов в приёмные родители является важным критерием оценки пригодности человека к выполнению социально значимой деятельности по воспитанию детей-сирот и детей, оставшихся без попечения родителей.

2. Структурно-уровневая модель оценки готовности кандидатов структурирует знания, определяет методологию, выделяет критерии пригодности и обосновывает 
подходы к социально-психологическому обследованию граждан, выразивших желание взять на воспитание в семью детей-сирот и детей, оставшихся без попечения родителей.

3. Структурно-уровневая модель оценки готовности кандидатов в приёмных родители позволяет определить риски и ресурсы человека, обеспечивающие снижение вероятности вторичного сиротства и жестокого обращения по отношению к принятым на воспитание в семью детям.

\section{Литература}

1. Алдашева А. А. Понамарева Е.А., Сиваш О.Н Особенности социальной идентичности замещающих родителей с разным количеством детей (Параграф 2.1) // Актуальные проблемы современной семьи : коллективная монография. Т. 1 / под науч. ред. д-ра психол. наук, профессора Н. В. Нижегородцевой. Ярославль : РИО ЯГПУ, 2018. - 179 с.

2. Алдашева А.А. , Зеленова М.Е., Понамарева Е.А. , Рунец О.В. , Структура ценностных ориентаций у замещающих родителей как предиктор эффрективности профессиональной приёмной семь, Материалы Всероссийской научно-практической конференции «Эффективность личности, группы и организации: проблемы, достижения и перспективы», Ростов-на-Дону; Курск, 21-22 апреля 2017 г., Кредо, Москва, 2017, 220 - 222.

3. Алдашева А.А. , Рунец О.В. , Зеленова М.Е., Стрессоустойчивость и стиль саморегуляции у приемных родителей, Психология стресса и совладающего поведения:ресурсы, здоровье, развитие. Материалы IV Международной научной конференции Кострома, 22-24 сентября 2016г., КГУ им. Н. А. Некрасова, Кострома, 2016, 2, 12 - 14.

4. Алдашева А.А. Признаки социально-психологической зрелости приемных родителей// Психологические проблемы семьи и личности в мегаполисе, Издво: Институт психологии РАН, 2012 г., С221-232.

5. Ананьев Б.Г. Человек как предмет познания.- Л., 1968.

6. Брушлинский А.В. Психология субъекта. СПб.: Алетейя., 2003

7. Дементий Л. И. Ответственность личности как свойство субъекта жизнедеятельности : автореферат дис. ... доктора психологических наук : 19.00.01 / Гос. ун-т - высш. шк. экономики. - Москва, 2005. - 45 с.

8. Кон И.С. Социология личности Издательство: Политиздат , 1967

9. Овчарова Р.В. Родительство как психологический феномен: учебное пособие. - М.: Московский психолого-социальный институт, 2006. - 496 с.

10. Постановление Правительства Москвы от 24 января 2014 г. № 8-ПП «О проведении в городе Москве пилотного проекта по имущественной поддержке семей, принявших на воспитание по договорам о приемной семье детей старшего возраста и (или) детей - инвалидов».) URL: 
https://www.mos.ru/dgi/documents/normativnye-dokumenty/view/180683220/ (22.07.2019).

11. Равен Дж. Компетентность в современном обществе. М.: Когито-Центр, 2002.

12. Харламенкова Н. Е. Спонтанность и контроль в зрелых личностных отношениях // Феномен и категория зрелости в психологии. М., 2007. С. 128148.

\section{STRUCTURAL-LEVEL EVALUATION MODEL OF PREPAREDNESS OF CANDIDATES FOR ADOPTIVE PARENTS}

Aldashseva A.A. (Institute of Psychology RAS, Moscow, Russia)

Ponamareva E.A., Sapozhnikova T.N. (SBI center "Childhood», Moscow, Russia)

This article presents the theoretical and scientific-practical premises for developing a system of selection of candidates for adoptive parents for a reception in the family of children of a complex category, presents a structural-level model for assessing the preparedness of candidates for adoptive parents, and describes the procedure for selecting candidates for adoptive parents.

Keywords: adoptive parents, competence, selection, socio-psychological maturity, preparedness. 